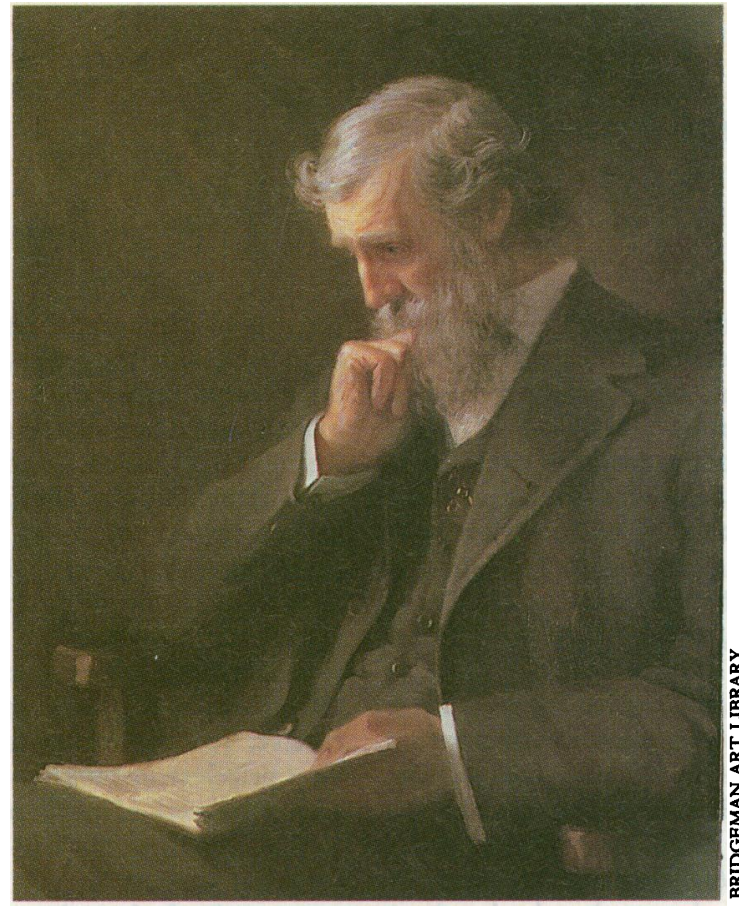

Beards: signs of wisdom or woolly thinking?

beard, ${ }^{1}$ shave less than their colleagues in the NHS Why?

Over 2000 years shaving habits have varied. Beards such as that worn by Van Dyke have eponymous status. Martial compared unshaven men to male goats, while Alexander led the Greeks and Scipio the Younger the Romans to shave daily-difficult without electric or modern safety razors. The coinage of many emperors and proconsuls depicts them bearded, and a young man's first shave of lanugo by the well paid tonsor was ceremonial-deposito barba. ${ }^{2}$ St Clement of Alexandria thought shaving effeminate, and since the Council of Calcedon so required, clergy of the Orthodox Church wear beards, often of magnificent size. Many teachers of Islam and Judaism are also bearded. Though the early Western Christian Church required clergy to shaveClerici barbam ne nutriant - the portraits of sixteenth century popes show them bearded, but in 1863 this innovation was discouraged and most Catholic secular clergy now shave. ${ }^{3}$

None of this resolves our disagreement. BP regards "Tarry at Jericho until your beards be grown" as endorsement of the maturity of men who have beards. He thinks that it is absurd that the association between beards and academic status confirms their mutual undesirability. He believes a later levee for academics acceptable by efficient use of the remaining hours they work.

JC, hesitating to speculate on the theory that a beard hides a weak face, knows that research is assembled to confirm what is obvious. Only the ecclesiastical evidence and fear of divine retribution prevents him concluding that beards and academic status each prove the weakness of the other. He lays store by a seventeenth century proverb, reminiscent of Martial's view, "If the beard were all the goat might preach."

We thank Father Peter Ingman, priest of the Catholic Diocese of Nottingham, and Father Denis Gill, Russian Orthodox Priest, for their help.

Funding: None.

Conflict of interest: BP, academic, has a moustache; JC, a shaver, is an NHS consultant.

1 Braun-Falco O, Plewig G, Wolff HH, Winkelmann RK. Dermatology. New York: Springer, 1991:757.

2 Carcopino J. Daily life in ancient Rome. Harmondsworth: Penguin, 1956 (Translated by EO Lorimer.)

3 Addis W, Arnold T. A Catholic dictionary. London: Virtue, 1954

4 Holy Bible (King James Version) 2 Samuel x, 5.

5 Browning DC. Dictionary of quotations and proverbs. Everyman edition. London: Dent, 1987.

\title{
Recharging the batteries
}

\author{
Kieran Murphy
}

Parachuting into someone else's life for a few days does not, on the whole, yield anything very deep in the way of experience. But it offers glimpses, hints, possibilities. The turned door handle admits a crack of light, and you can always return later to open it wide, step inside, and take up serious residence in the room you spotted on that flying visit.

JONATHAN RABAN in For Love and Money ${ }^{1}$

Thousands of British doctors spent electives in underprivileged countries, and some may be asked about their experience at interviews many years later. I say this because every job interview I have had since 1986 has been defined by questions about Tibetan Buddhism. This stems partly from an article that I wrote in 1985 about my two months in a Tibetan refugee camp on southern India. ${ }^{2}$

It became a merit badge and a career asset. It gave me an edge, and perhaps allowed the transfer of attributes to me that I knew I no longer deserved. To redress this imbalance my wife, a paediatric nephrologist, and 1 , an interventional neuroradiologist, took our year's vacation and returned to the monastery.
In a world filled with refugees it is fortunate for the Tibetans that they are a marketable minority. Tibet has

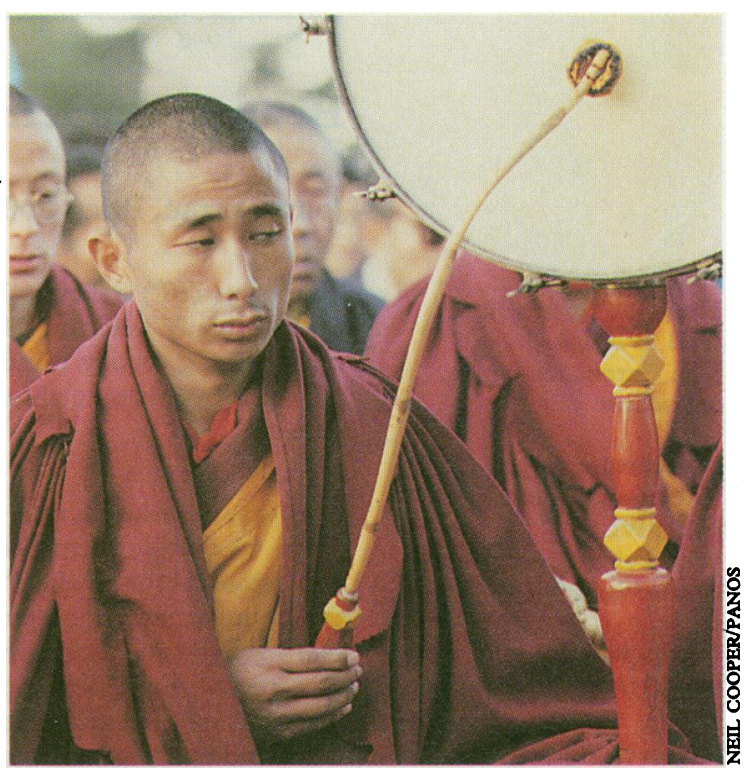


always been intriguing with its Buddhist philosophy that enchants with the hope of enlightenment and calm. Austine Waddell, a Buddhist scholar and member of a British expedition to Tibet in 1910, wrote in his book, Lhasa and its Mysteries: "Wreathed in the romance of centuries the secret citadel of the "undying" Grand Lama has stood shrouded in impenetrable mystery on the roof of the world, alluring yet defying our most adventurous travellers to enter her closed gates with all the fascination of an unsolved enigma, the mysterious city has held the imagination captive, as one of the last of the secret places of the earth, as the Mecca of East Asia."

The insatiable appetite for meaning, insight, and inner harmony has ensured the Tibetan community in exile is thriving. In every college town in America a "Free Tibet" bumper sticker is de rigueur on every student's battered car. Donations from pupils, book sales, lecture tours, and recordings of sacred chants have provided a lucrative source of income for many monasteries.

\section{Shuffling feet and baking bread}

Because of the disputed Indo-Chinese border, Tibetan refugees in India are a politically sensitive issue. The monks of Ganden monastery live in a refugee camp in a military restricted area, and foreigners require special permission to enter. After the publication of my first article I was denied a visa to return on several occasions. In February 1996, lacking the necessary visas, we arrived in the monastery quietly during the night. I woke the next morning to the sound of shuffling feet in the corridors, muffled voices, water pouring out of buckets, and the scents of sweet incense, baking bread, and boiling butter tea. Soon the guttural, mesmerising, tantric chants, sporadic cacophony of cymbals, and deep horn blasts of morning prayers started. The sun rose behind the yellow temple roofs, silhouetting tigers and gargoyles as prayer flags fluttered in a gentle morning breeze. In the 11 years since I lived there two huge new temples had been built. The monks now live in conditions superior to their Indian neighbours, whom they employ as farm labourers.

Three generations of monks are now discernible within the monastery, by virtue of their age, diet, and pleasures. The oldest monks were born and educated in Tibet and escaped in 1959. These senior monks do not approve of music or games and use copious amounts of snuff. They prefer a traditional Tibetan diet of tea made with butter, salt, tea, and milk, and bland food rich in salt, fat, and noodles. Next, there is the middle group, born in exile, educated in Tibetan monasteries based in refugee camps in India, Nepal, and Bhutan, who prefer Indian sweet tea, spicy Indian foods, and Hindi pop songs. They are multilingual and act as translators for their older teachers. Finally, the youngest group of teen-

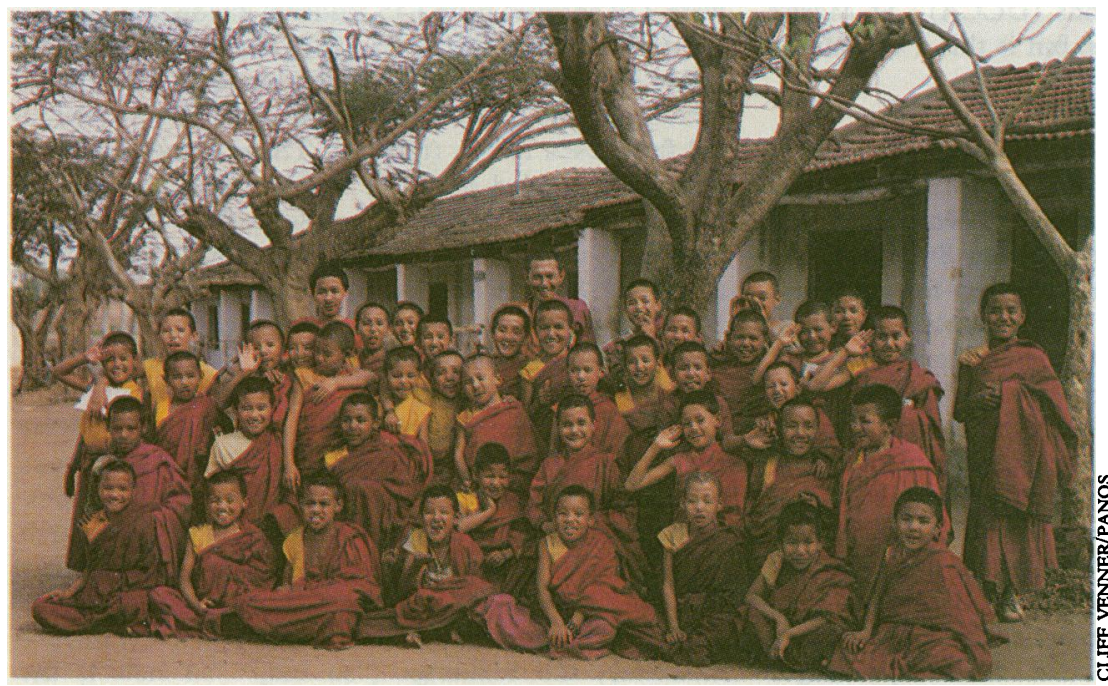

age monks were born in Tibet and have escaped to study to become monks in India. The recent arrivals from Chinese-occupied Tibet drink black tea, listen to Chinese music, and love to play games. They are the most militant, having experienced the Chinese occupation at first hand.

\section{Release of childish energy}

We arrived during Molam, the Tibetan new year celebration, spanning five days when the monks are allowed to play games. Three hundred and sixty days of pent up, childish energy was released by playing soccer, shuffle board, cards, and cricket until after dark.

Until its invasion and military occupation by the Chinese, Tibet had been extraordinarily self contained. This isolation was heightened by the lack of an airport roads, or even basic telecommunications. The great monastic settlements of Gyantse, Ganden, Drepung, and Sera housed up to 8000 monks, who lived, worked, prayed, or studied according to their talents in a feudalistic, religious warren. These monasteries and many smaller ones were destroyed and 1.2 million Tibetans have been murdered by the Chinese army since 1959 .

A monk studies until the age of 40 , when his childhood officially ends. Much of this time is devoted to the study of compassion. The student then sits his Geshe exam (or PhD thesis), a process of rigorous logical argument that takes several days. When I visited the monastery 11 years ago approximately 100 monks born and educated in Tibet lived and taught in the recreated Ganden Monastery in exile. There are now only two monks alive who completed their philosophical training and attained their Geshe degree in Tibet. This is still a principally aural tradition of teaching, and mere documentation by monks and Western scholars cannot reproduce the philosophical nuances fostered in the unique environment of the Tibetan plateau that are being lost through attrition. The older monks restrain the younger monks from going to the West, where they could become corrupted and lose focus.

As the older monks die and their unique knowledge is lost, the emphasis on health care in the monastery has become greater. Jigme Wangdu, the monk I worked with so closely 11 years ago, has risen to prominence in the monastery and is expected to be a future abbot of Ganden Monastery. $\mathrm{He}$ is actively avoiding this, however, as he feels that monastery politics will interfere with his spiritual development and will have a deleterious effect on his next life. He has developed a clinic and has sent two young monks to be trained as barefoot doctors.

\section{Improved diet and hygiene}

Eleven years ago we worked to broaden the monastery diet. This has happened as the monastery's wealth has increased and their farming skills have developed. In order to provide fruit for the diet and a cash crop to fund the dispensary we planted 110 mango trees. The plantation thrived for seven years until a blight struck and killed $70 \%$ of the trees. Impressed by the success the monastery intends to plant 80 acres of mango trees in the near future.

We successfully chlorinated the well water. Some of the older monks blamed this for causing worms and interfering in their meditation and the practice was stopped after a few months. Fortunately, most taps now have filters on them and boiling drinking water has become routine. In 1985 each water pump was surrounded by a muddy swamp, making it impossible to wash or clean. We built enormous, concrete washing areas that have survived, and they have been copied all over the camp.

The second part of our journey was to go to Kathmandu to the primary school for Tibetan children that I had helped to start in 1987 and had not visited since 1989. This school is run by Jigme Wangdu's 
brother, Tempa Tsering, and his family. We remained in touch, and I altered the plans of anyone who was visiting Nepal to include a visit to the school. The emphasis is on the education of children in reading, writing, and rehydration. The initial plan had been to educate street children; however, as the school became established, more affluent parents began sending their children and paying fees. These parents objected to the presence of street urchins mingling with their children. Tempa gets around this by taking in the street children during the three month summer break and making them presentable before the school year begins. This compromise ensures that the school is almost financially independent and accommodates 220 children, from 4 to 16 years of age.

\section{Leaving behind something useful}

Many aid organisations are bureaucratic and demand commitments that cannot be worked into a career or family. This represses expressions of altruism and goodwill. The ideals that drove us in medical school to go to underprivileged areas can get dulled. More and more people travel for pleasure in undeveloped countries where hospitals are frequently identified in guide books in case of emergencies. With a little planning, perhaps a few telephone calls or faxes to the local hospital, we could leave behind something more useful than our foreign currency. This also enriches the journey, and perhaps crosses the line between tourism and travelling.

You don't need to commit a month or a year to make a difference. To maximise our trip to Nepal, I identified the main public hospital in Katmandu-Tribhuvan Teaching Hospital-from an article in the American fournal of Radiology ${ }^{3}$ and contacted the hospital by fax. It replied that it had run out of guidewires and was unable to perform any angiography, nephrostomies, or hepatic abscess drainages. Scavenging around the Department of Radiology at the University of Michigan, I found approximately $\$ 15000(£ 10000)$ worth of visceral and neuroradiology catheters, guide wires, arterial needles, and stop cocks which had passed their use by date and were being thrown out. This is an alien concept to the Nepalese who resterilise and reuse everything. These supplies, three hours of lectures on slides, and four of the latest edition textbooks filled a second suitcase.

I do not mean to be condescending but we cannot underestimate the difference that a little potential energy (or a suitcase of catheters) makes to the place we visit. Since returning to the United States we have sent out two more boxes of catheters as large as the first. If properly coordinated there are enormous untapped resources in our departments. This activity could be made easier if coordinated by a Web site, a virtual aid agency. A low cost, aid agency, essentially a bulletin board, with no meetings, where information could be exchanged between travellers, health care workers, and local hospitals with specific needs. This would benefit the former spiritually and the latter logistically.

This trip allowed us, once again, to regain perspective on the preoccupations of the present, to reidentify the initial motivations that have become blurred by years of toil, and to ward off, for a while, the deadening effect of maturity. As Herman Melville said in Moby Dick: "Whenever I find myself growing grim about the mouth; whenever it is damp, drizzly November in my soul; then I account it high time to get to sea as soon as I can. I quietly take to ship."

1 Raban J. For love and money. London: Collins and Harvie, 1987:163.

2 Murphy K. Planting mangoes for the future in Tibet. BMF 1986;293:1649-

Brant WE. Budathoki TB, Pradhan R. Radiology in Nepal. Am $f$ Radiol 1996;166:259-62.

\section{Why do medical students choose St Mary's Hospital Medical School?}

\section{J H Baron}

For many years St Mary's Hospital Medical School in London has had the highest number of applicants per place in Britain. For entry in October 1996 there were 2700 applicants for 100 places. St Mary's has published extensive data of its audit of admission ${ }^{1-3}$ and in 1990 inquired which of 22 factors influenced the 5872 applicants to the 28 British medical schools to make their five choices on the form from the Universities' Central Council on Admissions (UCCA). ${ }^{4}$ St Mary's was rated high on friendliness, but is this a continuing perception?

\section{Subjects, methods, and results}

From 1971 until my retirement in 1996 I asked 344 men and 301 women who had chosen St Mary's one question "Why St Mary's?" at interview for entry and when students began on my firm or applied to be my house physician. For simplicity the category "friendly" included the following answers: caring, character, close knit, community, cosy, enjoyable, everyone knows each other, fun place, kind, lovely, nice, open, outside activities, small, stress free, supportive, taking interest, warm, and welcoming. "Adviser" might be a relative, teacher or tutor, or family doctor. "Academic" included the quality of teaching and research and adequacy of patient numbers for clinical experience. "Low grades" meant that students knew that St Mary's might interview them even if it was placed low on their UCCA form and that they might be accepted if they were outstanding at interview even if they achieved less than the minimum grades or if they had to retake their A level examinations (see table 1 ).

Most people gave one reason why they had chosen St Mary's, which was scored 1, but a few gave two or three reasons, which were scored a half or a third. Thus there were 779 answers from 645 students divided by sex and by date of entry (1971-82 (258) and 1983-4 (387)) (table 1). Over the 25 years choice made on friendliness increased from $52 \%$ to $70 \%$ while choice by an adviser fell from $29 \%$ to $6 \%$ (table 1). Those citing academic reputation trebled from $2 \%$ to $7 \%$, but four chose $\mathrm{St}$ Mary's for the opposite opinion: "not too much pressure, not an academic hot house, not high powered." Sport was cited by $7 \%$ of the men but only $3 \%$ of the women, and music was mentioned by $2 \%$. Those choosing St Mary's because of its prospectus decreased from $7 \%$ to $2 \%$. St Mary's location in London (west central) was cited by $2 \%$ and a similar proportion had been impressed by St Mary's willingness to consider low UCCA ranking or low retaken A grades.

Miscellaneous answers included liking the research (AIDS, tropical diseases, cystic fibrosis) or researchers (Fleming or Almroth Wright), the name ("my school," "my middle name"), the dean's annual book (Learning Medicine), the buildings ("so old," "so new"), the 